\title{
Digital Transformation, Business Model Innovation and Efficiency in Content Industries: A Review
}

\author{
Rojers P Joseph \\ Strategic Management Area, Indian Institute of Management Rohtak \\ Rohtak, Haryana, India 124001 \\ Email: rojers.joseph@iimrohtak.ac.in
}

\begin{abstract}
Owing to the symbolic, highly digitizable nature of the goods the content industry produces, they are highly amenable to digital transformation with radical consequences for businesses selling information products. Digitization and digital networks can save several costs that are inherent in the brick and mortar value chain in the content industry. This transformation creates newer values at several points in the value chain, leading to the emergence of newer business models that enlarge the existing business pie by attracting new customers or encouraging the existing customers to consume more. However, price dispersion that results from product heterogeneity, convenience-seeking user behaviour, consumer awareness, retailer brand equity and trust, and higher switching costs leads to inefficiency in Internet markets. Thus, the pricing strategies suitable for information products differ from that for physical goods - price discrimination and product bundling being two commonly and successfully used pricing strategies for digitized information products.
\end{abstract}

Keywords: Content Industry; Information Products; Digitization; Business Models; Electronic Markets; Pricing Strategies

\section{Introduction}

The content industry is made up of firms owning and providing products and services such as music and movies, text publications, geographic data, ownership of standards and metadata on any of these products and services. The growing adoption of information and communication technology (ICT) in all areas of the economy is changing the way goods are produced, distributed and consumed ${ }^{1,2}$. This change is denoted by the term 'digital transformation' which is understood as "the changes that the digital technology causes or influences in all aspects of human life"3. For businesses, it is about integrating digital technology into all functions, fundamentally transforming the way they operate and deliver value to customers. The content industries, as a consequence of the symbolic, highly digitizable nature of the goods they produce, are amenable to this transformation with radical consequences for businesses operating in a digital economy 4 .

In this context, this paper summarizes the relevant literature on theories pertaining to digitization and the emergence of newer business models in content industries. To this end, the paper reviews close to fifty research articles in the areas of information technology, innovation, business management and economics. The review focuses on characteristics of information products, cost savings in the digital value chain, dimensions of efficiency and causes of price dispersion in electronic markets, and pricing strategies for information products.

\section{Digital Economy: Meaning}

According to Zimmermann ${ }^{5}$, an economy based on digitization of information and the respective 
information and communication infrastructure is called digital economy. By digital economy we mean an economy of abundance where material resources are not scarce. Digital economy is closely related to information economy in which information is not merely a tool but a product, and knowledge is the prime raw material and source of value 6 .

Borgman $^{7}$ emphasizes the role of three factors in enabling access to information: technology, human behaviour and policymaking. The success of the global information infrastructure is all about recognizing the behavioural aspects of adopting and adapting new technology into our lives, utilizing it efficiently, and establishing policies concerning the ownership and distribution of information. Digital networks and content digitization can play a pivotal role in enabling access to information from around the world, if policies that adequately address the concerns of providers and users of digitized information are in place.

\section{Characteristics of Information Products}

Information goods are typically different from tangible physical products in several ways ${ }^{8}$. Information products are said to be non-rivalrous and nonexcludable ${ }^{9}$. Non-rivalrous means the use of a product (e.g. listening to a music album) by one person does not diminish the utility of using the same product by another. Information, as a public good, is nonexcludable which means accessing a piece of information by one person cannot exclude others from accessing it (e.g. free-to-air TV broadcasting). These characteristics greatly apply to digitized content audio, video, text and graphics - where the transformation from atom (physical) to bits (digital) is fast-paced ${ }^{10}$.

The other characteristics of information products that differentiate them from physical goods in a market environment are: cost structure, transitory nature ${ }^{8}$, reliance on customer experience 8,11 , customizable nature, network effects, and switching costs/lock-in ${ }^{8,12}$. First, information goods, unlike physical products, are characterised by high fixed (sunk) costs and very low or near-zero marginal costs. Such a cost structure generates massive economies of scale, as there are virtually no capacity restrictions. As a result, the primary concern of most information good producers would be about quality and the number of versions to offer rather than the level of investment in capacity and quantity. Firms may have to devise new valuebased pricing strategies because the traditional costbased pricing strategies can be misleading ${ }^{13}$.

Second, information products are highly transitory in nature with time-dependent values, which would render such products obsolete in a short period of time. With digitized information products, there is an everincreasing scope for making regular updates of contents online as in online books and journals. Third, information goods are experience goods, as users are able to assess the quality of goods only after their consumption, which can lead to information asymmetries across markets. Fourth, individual preferences have a strong influence in determining the value of a piece of information, as digital products are alterable. Individual preferences would act as a strong incentive to customize and personalize information products, unlike in the case physical products.

Fifth, the network effect or external consumption effect which means the customers' appreciation of a product rises as more units of information products are sold. This would ultimately lead to demand-driven economies of scale in information product markets. Finally, durable investment in complementary assets is often a requirement for information products. For instance, customers may need training on how to use information products sold by a particular vendor. These investments would be lost if a customer switches to another brand, often resulting in substantial costs.

\section{Attributes of Digitized Content}

As information products are highly amenable to digitization, it is important to consider the attributes that differentiate digital objects from non-digital objects. Digitized content is editable, interactive, open, and distributed ${ }^{14}$. 'Editable' means digital objects are pliable and can be acted upon and modified continuously and systematically. Digital objects are 'interactive', as they offer alternative ways in which humans can activate functions embedded in the object or explore the arrangement of information items underlying it (for instance, hypertext) and the services it mediates. Digital objects are 'open' because they are accessible to and modifiable by another program or digital object. 'Distributed' nature of digital objects means they are seldom contained within the 
boundaries of a single source or institution. Networked digital media does not have an identifiable border defining it as an obvious entity, unlike packaged and single media, like books.

Besides the above attributes, 'modularity' and 'granularity' in the composition of digital objects make them pliable and divisible into small components, each of which can be distributed, worked upon and used independently15,16. Modularity allows local manipulation of digital objects without any significant effects on the larger system of technical relations into which the object is embedded. Granularity sets digital objects apart by making possible two groups of operations: first, granularity helps trace the behaviour of a digital object to several layers of underlying operations (for example, data-mining of a database) by which it is sustained; and second, granularity enables minute and piecemeal intervention (for instance, editing Wikipedia or development of open source software). Both modularity and granularity have direct implications for digitized information products, both in content creation and management ${ }^{17}$.

Table 1 Attributes: Digitized goods vs Physical goods

\begin{tabular}{ccc}
\hline Attribute & Digitized goods & Physical goods \\
\hline Editable & Yes & No \\
Open & Yes & No \\
Interactive & Yes & No \\
Distributive & Yes & No \\
Modular & Yes & No \\
Granular & Yes & No \\
Indestructible & Yes & No \\
Transmutable & Yes & No \\
Easily reproducible & Yes & No \\
\hline
\end{tabular}

Source: Compiled by author

The above properties of digital content bestow three characteristics that distinguish digitized information products from physical goods: indestructibility, transmutability, and reproducibility ${ }^{7}$. Indestructibility means digital goods undergo no wear and tear (provided the physical objects such as compact discs in which they are held last longer); transmutability means digital goods can easily be altered or combined to form new products; and reproducibility refers to the easiness of producing digital copies at very low cost. Digitization has resulted in an increase in quantity, quality and variety of goods and services made available in the economy, leading to a general rise in social welfare ${ }^{18}$.

\section{Value creation through Digitization}

The value chain is a series of activities that create and build value over time and will add up the sum total of values delivered by an organization. Inbound logistics, operations, outbound logistics, marketing and sales and services are the primary activities in a value chain, while firm infrastructure, human resource management, technology and procurement are the support activities ${ }^{19}$. Technological advancement is identified as a crucial factor that influences the value chain from time to time. With the emergence of digital technology and digitization of information, the value chain in content industries has undergone significant transformation with the creation of newer values. Value creation in the form of cost savings through digitization is a major outcome of digitization.

Digitization and digital networks can save several costs that are inherent in the brick and mortar value chain in the content industries. Several studies have conclusively shown that digitization which leads to lower costs of production and distribution and quicker dissemination of information is creating new values in the digital economy. The costs of reproduction, distribution, and inventory, and the costs of transaction are among the major expenses saved through digitization.

\section{Cost of Reproduction}

Digitization dramatically brings down the cost of reproduction, with the marginal costs of making additional copies falling to very low levels ${ }^{10,20}$. Thousands of digital copies can be prepared at the click of a button and sent over the Internet in quick time. Consequently, as the production of digital goods increases, the marginal and average costs decrease and income increases ${ }^{21}$. This possibility also frees the content industries from the shackles of diseconomies of scale associated with low volumes resulting from uncertainties of demand 22 . 


\section{Cost of Distribution}

Distribution intermediaries such as wholesalers and retailers take a major share of the revenues obtained from selling conventional physical products. The emergence of the Internet as a worldwide distribution channel for goods and services has greatly helped producers eliminate intermediaries from the value chain ${ }^{23}$. Digital content also benefits from the ability to exploit various strata of consumers that can be classified by the intent-to-use and the immediacy-ofneed. By using the Internet, a large variety of digital content may be easily disaggregated and distributed on demand, thereby reducing the cost of distribution to very low levels ${ }^{8,24}$.

\section{Cost of Inventory}

Brick and mortar stores maintain an inventory of physical products leading to various costs related to purchasing, transporting, receiving, unpacking, displaying, storing and selling. In e-commerce, retailers can create a working relationship with wholesalers or manufacturers that ship directly from their facility, which is often called drop shipping 25 . This leads to savings in the costs incurred for processing and housing of inventory.

Saving in storage costs has a different implication for digitized content. Moore's law states that storage capacity of computer chips doubles every two years. To state differently, it lowers the cost of storing the same amount of data by half every two years. The explosive growth in digital technologies and Internet makes it possible to store and process enormous amount of digitized data at minimal cost. This is expected to bring in huge changes in content industries such as publishing, as the cost of storage, obsolescence and returns from retailers in conventional physical products can be greatly reduced.

\section{Transaction Costs}

Costs associated with the exchange of goods are called transaction costs. Physical markets with market friction result in transaction costs borne by suppliers and consumers. Intermediaries help reduce transaction costs in physical markets.

Transaction costs play an important role in Internet markets because virtually every valuable activity on the Internet involves multiple participants - vendors of hardware and software, non-commercial participants, and users ${ }^{26}$. By promoting interoperability, the Internet may reduce transaction costs inherent in exchanges between suppliers and consumers ${ }^{27-29}$. Significantly, the possibility to reduce transaction costs on the Internet may prompt online suppliers to transact directly with customers by avoiding the intermediary route $^{28}$. Selling digitized content would lead to savings in the following transaction costs in the value chain.

\section{Search Costs}

Based on the traditional economic view, high search costs in traditional markets will result in high prices in the long run equilibrium ${ }^{30}$. The Internet should reduce search costs for consumers, thereby making the markets more competitive through price reduction ${ }^{27,31}$. Empirical evidence from the US Life Insurance industry showed that the Internet helped bring down term-life prices by 8 to 15 percent and increase consumer surplus by at least $\$ 115$ million annually 32 . Digitization has huge potential to improve access to products/services by improving the convenience of buying 33 and by enhancing the comprehensiveness (wider selection) of the products and services offered $^{34-36}$.

\section{Cost of Price Dispersions}

In economic theory, price dispersion occurs when different prices are charged for the same product at the same time ${ }^{37,38}$. Considerable anecdotal evidence is available on the benefits of increased access to price information by the use of digital technologies ${ }^{32,36}$. As customers can make price comparisons between hundreds of vendors, prices come down to a competitive level. Decreasing search costs on the Internet would also lead to lower price dispersions ${ }^{27}$. It is reported that near-zero price dispersions can be an outcome of electronic markets ${ }^{29}$. As information becomes increasingly available, it enables customers to make proactive decisions with changes in market forces. Combining the unique characteristics of digitized information products and the potential for large cost savings in the value chain, some of the emerging digital business models help create significant value in the market for information products. 


\section{Business Models in the Digital Era}

The concept of business model has been commonly used in trade and economic parlance since pre-classical times $^{39}$. A business model is the method of doing business by which a company can sustain itself through revenue generation. The business model explains where a company is positioned in the value chain and how it makes money. Some of the models are quite simple as in manufacturing where manufactured products are sold to the customers. If the revenue from sales exceeds the cost of operations, the firm will make a profit. Some other models are quite intriguing as in broadcasting where the broadcaster is a part of the complex network of content creators, distributors, advertisers and listeners or viewers. Zott et al. ${ }^{40}$ contend that an explicit definition of the concept is often missing in majority of the literature on business models, even though the concept became ever more prevalent with the spread of the Internet since the mid-1990s.

\section{Brick and Mortar Business Models}

The brick and mortar business model is a term used in the Internet era to differentiate between the pure online models and the real world physical models. Brick and mortar businesses usually have a physical address where face-to-face interaction with customers happens ${ }^{41}$. This model is suitable or essential for certain types of businesses such as auto-repair and healthcare, as hands-on experience is needed to provide the goods or services. Prior to the arrival of the Internet, all firms selling goods and services used the brick and mortar model invariably. While brick and mortar businesses suffer from several cost disadvantages such as land costs, property taxes, insurance costs and larger employee costs, customers' higher trust levels and sense of security is an advantage they have over the internet-based models. In the content industry, physical bookstores and video rental shops are brick and mortar models that are struggling to survive the onslaught of e-commerce models and online digitized content.

\section{2. $\quad$ E-commerce models}

The global reach of the Internet provided the brick and mortar models to leverage the possibilities offered by the World Wide Web to do business through online transactions ${ }^{23}$. Electronic commerce has given rise to newer web-based business models that often have aspects that are the least understood ${ }^{42}$. Some of the tremendously successful e-commerce models such as Amazon and Netflix are giving the brick and mortar businesses a run for their money. Lower overheads in operations, the convenience of one-click buying, and the extravagance of choosing from a huge collection of products made these models an instant success ${ }^{35}$.

Table 2. Comparing brick and mortar and e-commerce models

\begin{tabular}{lll}
\hline Aspect & $\begin{array}{l}\text { Brick and } \\
\text { mortar model }\end{array}$ & $\begin{array}{l}\text { E-commerce } \\
\text { model }\end{array}$ \\
\hline Overheads & High & Low \\
Convenience & Low & High \\
Selection & Small & Large \\
Trust & High & Low \\
\hline
\end{tabular}

Source: Compiled by author

\section{Pure-play Digital Models}

At the other end of the spectrum, pure-play digital models sell only digitized content such as music, movies and textual data and unlike e-commerce models such as Amazon.com, do not sell any physical products. Apple's iTunes, which sells music online, and Ebrary.com, which sells digitized books, are examples of pure-play digital business models.

\section{Click and Mortar Business Models}

The spread of the Internet and the growth in ICT have enabled the brick and mortar firms to leverage the flexibility and convenience offered by the web to enhance their existing operations. This led to the emergence of "click and mortar" business models or "cyber-enhanced retailing" whereby the physical outlets' operations are supplemented by e-commerce capabilities on the web ${ }^{43}$.

For instance, the customers of Wal-Mart, the world's largest retailer, can buy goods from its retail stores and also order online without visiting the store. Banks, through electronic fund transfer, are also transforming themselves into click and mortar. The click and mortar business models bring enormous synergy to business operations, by combining the 
features of physical and digital value chains. Steinfield et al. ${ }^{43}$ describe four types of synergies resulting from the integration of e-commerce and physical infrastructures namely, cost savings, improved differentiation, enhanced trust and market extension.

Book publishing, a constituent of the content industry, currently operates all the four models described above. Traditional brick and mortar bookstores still operate all around the world. Amazon, an online retailer, is an e-commerce model that sells both eBooks and print books. Ebray.com and NetLibrary, which are pure-play digital models, sell only digitized books. Barnes \& Noble which sells both print and digital books through its online store and physical stores has evolved into a click and mortar business. However, Netflix, another player in the content industry, is gradually moving away from the click and mortar model to pure play digital movies streaming model.

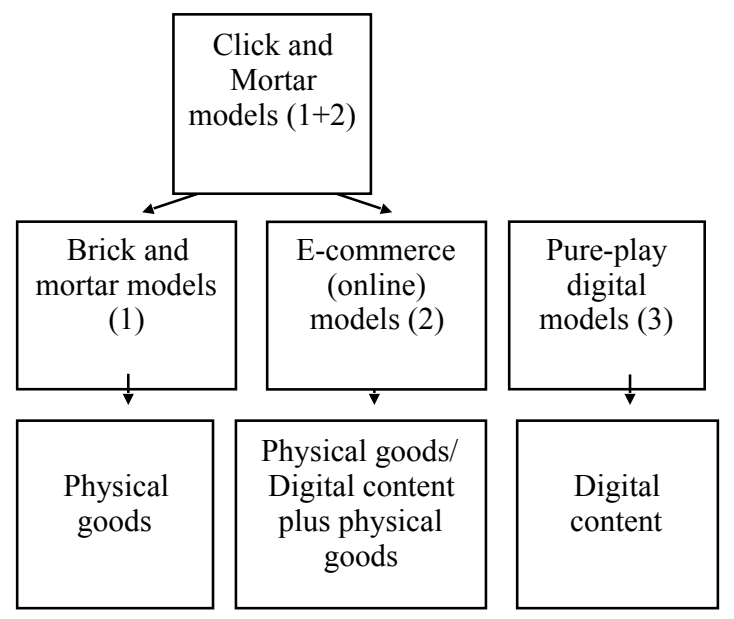

Figure 1. Business models in the digital era Source: Created by author

A business model innovation is expected to enlarge the existing business pie by attracting new customers or encouraging the existing customers to consume more. Business model innovators do not invent a new product or service. Rather they simply redefine how an existing product or service is provided to the customer. Digital publishing platforms, online book retailers and print on demand publishing are disruptive business model innovations. For instance, Amazon did not discover book selling but redefined it.
Content digitization and the spread of the Internet have given rise to newer business models, resulting in varying levels of efficiency in the delivery of products or services in Internet markets. The following section discusses the factors that determine the efficiency of business operations carried out in Internet markets.

\section{Dimensions of Efficiency in Internet Markets}

Smith et al. ${ }^{31}$ have identified four dimensions of efficiency in Internet markets, namely price levels, price elasticity, menu costs and price dispersions. These four dimensions are briefly described here.

\section{Price Levels}

Lower prices for products sold on the Internet as compared to those sold by the brick and mortar stores will result in price level efficiency in Internet markets. Two factors can contribute to lower price levels in internet markets; one, lower search costs and two, better retailer cost structure. Lower search costs may lead to lower prices by allowing consumers to more easily determine retailers' prices and product offerings. Improved cost structures may lead to efficient pricing in two ways. First, low entry costs will limit the price premiums charged by incumbents through increased competition ${ }^{43}$. Second, favourable cost structures can lead to lower price levels in the long run by decreasing the underlying costs on which premiums are based.

Empirical evidence does not fully support the view that prices of products sold by the Internet retailers are lower than that of products sold by the brick and mortar retailers ${ }^{33}$. Smith et al. ${ }^{31}$ compared the results of several studies $28,45,46$ to show that price efficiency in Internet markets depends on the nature of goods and transactions. For instance, an internet auction market for used automobiles may not achieve lower price levels as compared to physical markets due to reasons such as reputation of the online marketer and better quality of cars sold online. Also, some Internet markets may not be price efficient in the early years, but may achieve efficiency as they mature over a period of time 28,33 .

\section{Price Elasticity}

Price elasticity is a measure of how sensitive consumers' buying decisions are to change in prices. 
Based on traditional economic theory, consumers are more sensitive to small changes in prices, if the market is efficient. It is expected that higher price elasticity may result from lower search costs or lower switching costs in electronic markets.

Smith et al. ${ }^{31}$ who summarised the outcome of several studies on price elasticity in online markets found that internet consumers appear to be more sensitive to prices in conventional outlets than prices in online stores ${ }^{47}$. They are less sensitive to price differences between online retailers, thanks mainly to the characteristics of online shopping. Lower search costs will allow customers to locate products that more readily meet their demands so that they are less concerned about minor price variations ${ }^{48}$. Besides, the 'missing information' when buying products online will force buyers rely on other signals of quality such as brand rather than prices in choosing their products ${ }^{49}$.

\section{Menu Costs}

The costs retailers incur when making price changes are called menu costs. In brick and mortar businesses, menu costs are incurred to physically re-label products on shelves ${ }^{50}$. Empirical studies have found that menu costs are lower in online markets than in conventional markets and that the internet retailers make significantly more price changes than conventional retailers 28,46 . In fact, internet retailers are found to make price changes that are up to 100 times smaller than the smallest price changes observed in conventional outlets.

\section{Price Dispersions}

As search costs are lower and consumers are readily informed of prices in internet markets, price dispersions on the internet should be lower ${ }^{31}$. However, early empirical evidence provides mixed results on price dispersions in internet markets. Several studies supported lower price dispersions in online markets, compared to conventional markets $27,32,36$. Studies that did not support lower price dispersion in internet markets cited market immaturity and heterogeneity in retailer attributes as the major causes of price dispersion ${ }^{28,33,46}$.

In summary, reduced price levels, higher price elasticity, lower menu costs and minimal price dispersions are expected to lead to improved efficiency in electronic markets, as compared to physical markets. However, evidence shows that the level of efficiency achieved in electronic markets is often below par (Refer to Table 3). The following subsection discusses the sources of price dispersion, a major cause of inefficiency in electronic markets ${ }^{31}$.

\section{Sources of Price dispersion in Electronic Markets}

The existence of persistent and significant price dispersions in electronic markets would be a cause for concern. Smith et al. ${ }^{31}$ have identified six sources of price dispersion in electronic markets: (1) product heterogeneity, (2) convenience of shopping, (3) consumer awareness, (4) retailer branding and trust, (5) switching costs and (6) price discrimination.

Table 3. Dimensions of efficiency in electronic markets

\begin{tabular}{|c|c|c|c|}
\hline Dimension & $\begin{array}{l}\text { Expected } \\
\text { outcome }\end{array}$ & Causes & $\begin{array}{l}\text { E m p i r i c a l } \\
\text { study results }\end{array}$ \\
\hline $\begin{array}{l}\text { Price } \\
\text { levels }\end{array}$ & $\begin{array}{l}\text { Lower } \\
\text { price levels } \\
\text { in e- } \\
\text { markets }\end{array}$ & $\begin{array}{l}\text { Lower } \\
\text { search } \\
\text { costs; } \\
\text { Improved } \\
\text { cost } \\
\text { structure } \\
\text { (i.e. lower } \\
\text { entry costs) }\end{array}$ & $\begin{array}{l}\text { Mixed: e- } \\
\text { markets may } \\
\text { achieve price } \\
\text { level } \\
\text { efficiency } \\
\text { over time, as } \\
\text { they mature }\end{array}$ \\
\hline $\begin{array}{l}\text { P r i c e } \\
\text { elasticity }\end{array}$ & $\begin{array}{l}\text { Higher } \\
\text { price } \\
\text { elasticity in } \\
\text { e-markets }\end{array}$ & $\begin{array}{l}\text { Lower } \\
\text { search } \\
\text { costs; } \\
\text { Lower } \\
\text { switching } \\
\text { costs }\end{array}$ & $\begin{array}{l}\text { Mixed: online } \\
\text { consumers are } \\
\text { highly } \\
\text { sensitive to } \\
\text { prices in } \\
\text { conventional } \\
\text { outlets, but } \\
\text { less sensitive } \\
\text { to price } \\
\text { differences } \\
\text { between } \\
\text { online } \\
\text { retailers }\end{array}$ \\
\hline $\begin{array}{l}\begin{array}{l}\text { e } \\
\text { costs }\end{array} \\
\text { u }\end{array}$ & $\begin{array}{l}\text { Lower } \\
\text { menu costs } \\
\text { in e- } \\
\text { markets }\end{array}$ & $\begin{array}{l}\text { Lower costs } \\
\text { to make } \\
\text { price } \\
\text { changes in a } \\
\text { central } \\
\text { database }\end{array}$ & $\begin{array}{l}\text { Positive: } \\
\text { menu costs } \\
\text { are found } \\
\text { lower in e- } \\
\text { markets }\end{array}$ \\
\hline
\end{tabular}




\begin{tabular}{llll}
$\mathbf{P}$ r i c e & Lower & Lower & Mixed: \\
dispersion & price & search & market \\
s & dispersions & costs; & immaturity \\
& in e- & Better price & and \\
& markets & information & heterogeneity \\
& & & in retailer \\
& & & outlets may \\
& & & increase price \\
& & & dispersion in \\
& & & e-markets \\
\hline
\end{tabular}

Source: Compiled by author

Product heterogeneity means the products being compared are different in some way. Even physically identical products may not be good substitutes, as they may be available in different locations or time periods. Shopping convenience may provide price dispersion in online markets. Time sensitive consumers may be willing to pay a price premium for ease of search and better evaluation of products online. The customer awareness of online portals (for example, neural real estate) may be just as important in online markets as physical real estate is in conventional markets. Awareness plays a significant role as it reduces search costs to locate retailers, given the sheer volume of information available. Buyers in electronic markets may buy from a trusted retailer such as Amazon, even when these retailers do not offer the lowest price. This behaviour goes against the natural assumption that buyers who use intermediaries usually buy from the lowest price retailer. Trust may play a crucial role in retailer-buyer relationship in electronic markets because of the spatial and temporal separation imposed by the medium ${ }^{46}$.

Besides, if retailer-switching costs are higher, buyers in electronic markets will be ready to pay a premium. An example is the loyalty programs run by airlines, where the customers who switch to other airlines will lose certain benefits. Familiarity with the retailer's website would also create switching costs. Lastly, price dispersion may result from price discrimination, whereby retailer charges different prices for a product based on customers' willingness to pay.

\section{Pricing Strategies for Information Products}

As the efficiency in electronic markets is determined mainly by price-related factors and the electronic markets experience considerable price dispersions, the pricing strategies suitable for information products differ from that for physical goods. Near-zero marginal cost of reproduction for digitized information products rules out the possibility of setting the lower price limit as equal to marginal cost in competitive markets, based on traditional economic theory ${ }^{8}$. Information products have certain characteristics that allow other pricing strategies. The market for information products tend to be much more like the automobile market (monopolistic competition) than the wheat market (pure competition) ${ }^{20}$. As the marginal cost of producing information goods is very low, it is much easier to customize them for individual users ${ }^{13}$.

\section{Information Products and Price Discrimination}

Price discrimination is used when producers find it advantageous to charge different prices for different users when consumers have heterogeneous willingnessess to pay. Since consumers will not explicitly make their true willingness known, pricing will be based on something that is correlated to the willingness to pay ${ }^{20}$. For instance, business users are expected to have a higher willingness to pay for software products than educational users.

Versioning is another form of second degree price discrimination used for digitized information products $^{13}$. For instance, publisher can price discriminate based on the quality of a digitized book, say resolution. Customization and Versioning are both driven by the near-zero marginal cost of reproducing information goods.

\section{Information Products and Bundling}

Bundling is a common feature in imperfectly competitive product markets ${ }^{51}$. There are several ways in which firms can adopt a bundling strategy. In 'pure bundling', firms sell goods only in package form. Firm adopting a 'mixed bundling' strategy sell the same goods separately as well as in packages. In 'customized bundling' firms determine only the size and the price of the bundle they offer and the customers then decide the contents to be included into the bundles they would buy ${ }^{13}$. Though the profit potential improves with bundling of information products, the reduction in transaction and distribution costs for digitized content make disaggregation profitable in some cases, as in 'pure unbundling' 52 . 
Product bundling is desirable for information products $^{52}$ and is an attractive form of price discrimination ${ }^{20}$. Historically, goods sold in large bundles in conventional markets had been unprofitable and received little attention ${ }^{53}$. Modularity and granularity of digitized content enable digitized information products to be easily sold in bundles of desired sizes and combinations. Predictive value of bundling makes it possible to achieve greater sales, greater economic efficiency, and greater profits per good from a bundle of information goods than that can be attained when the same goods are sold separately. For instance, there are strong incentives for academic journal publishers to engage in 'mixed bundling', i.e. offer both individual articles and journal subscriptions ${ }^{54}$

Bakos and Brynjolfsson 52 showed that pure bundling is the optimal strategy for a multi-product monopolist under conditions of zero marginal cost and identically distributed customer valuation. They also showed that bundling substantially reduces the average deadweight loss as well as consumer surplus. Wu et al. 55 in a study found that customized bundling of information products leads to an increase in profits over pure bundling. Bundling of information goods reduces billing and administrative costs and eliminates the need for consumers to assemble individual components $^{13}$.

\section{Practical Implications}

In general, reduced price levels, higher price elasticity, negligible menu costs and lower price dispersions are expected to lead to improved efficiency in electronic markets. However, early evidence from empirical studies on price dispersions in internet markets is mixed. For instance, though online consumers are sensitive to prices in conventional outlets, they are less sensitive to price differences between online retailers because lower search costs will help customers locate products that more readily meet their demands. Moreover, market immaturity and heterogeneity among online retailers may increase price dispersion. Thus, in the fast-growing internet markets, differentiation based on 'convenience of buying' 31 and 'comprehensiveness of selection' 35 would be crucial for retailers.
Trust and brand awareness may play a large role in differentiating between online retailers. A trusted retailer may be able to offer prices that are not the lowest. This is contrary to the assumption in traditional markets that if intermediaries are used, buyers usually go for the lowest price retailer. Thus, trust may play a crucial role in retailer-buyer relationship in Internet markets because of the spatial and temporal separation created by the online medium.

As the marginal cost of producing information goods is negligibly low, retailers can easily customize them or use 'versioning' for individual customers. While 'bundling' of digitized information products can significantly reduce transaction, distribution and administrative costs, 'unbundling' too can be profitable (for example, selling individual chapters of a digitized book). All these have practical implications for decision making for managers of electronic retailers both small and large.

\section{Limitations and Future Research Directions}

The focus of this paper is business model innovation pursued by online retailers and efficiency in electronic markets. To this end, the literature reviewed in the paper pertains mainly to the Web 1.0 technology. However, with the emergence of the Web 2.0 technology and the spread of social media, users are allowed to contribute content, which can be monetized. This growing trend is further transforming the online content market, as contribution by users affects the pricing of information products ${ }^{56}$. This may be viewed as a limitation in the context of this paper, as the economic impact of user-generated online content is further advancing the frontiers of electronic commerce and opening up new research avenues in this area.

\section{Conclusion}

Digital economy is an economy of abundance, as it is not constrained by physical resources unlike the traditional economy. The growth of information and communication technology and content digitization are changing the way information goods are produced, distributed and consumed. Digital goods, because of their nature, are fully replicable (copied without loss of information) at negligible cost. 
Major costs that could be saved in the digital value chain include the costs of reproduction, costs of intermediation and transaction costs. In physical markets, intermediaries help reduce transaction costs. The possibility to reduce transaction costs on the Internet prompts online sellers to transact directly with customers by avoiding the intermediary route.

Digitization has transformed the traditional brick and mortar business models for good. Online ecommerce models, pure-play digital models, and click and mortar models all bring enormous synergy to business operations by combining the features of physical and digital value chains. Digital technologies, combined with the right policy framework and an interface that enhances user-friendly access, would play a significant role in improving the dissemination of information products.

Empirical studies on the four dimensions of efficiency in electronic markets have provided mixed results. Menu costs were found much lower in electronic markets as compared to conventional markets. Price levels, price elasticity and price dispersions were not significantly lower in electronic markets than in conventional markets. Product heterogeneity, price discrimination, branding (trust), and switching costs cause price dispersions in Internet markets.

Apart from being non-rivalrous and nonexcludable, information goods differ from physical goods in several other ways. The cost structure of information products generates massive economies of scale, as there are virtually no capacity restrictions. They are transitory (time-dependent) in nature with positive network externalities, substantial switching costs, and plenty of scope for product customization. Price discrimination and product bundling are two commonly and successfully used pricing strategies in markets for information products.

\section{References}

1. K. Hamidian, and C. Kraijo, DigITalisierung-Status quo, in Digitalisierung und Innovation (Springer, 2013) pp. 1-23.

2. F. Hungerland, J. Quitzau, C. Zuber, L. Ehrlich, C. Growitsch, M. C. Rische and H. J. Hab, The digital economy (No. 21e). Strategy 2030-Wealth and Life in the Next Generation, Hamburg Institute of
International Economics (HWWI). https:// econpapers.repec.org/paper/zbwhwwist/21e.htm

3. Stolterman, E. and A. C. Fors. "Information Technology and the Good Life." In: Information Systems Research: Relevant Theory and Informed Practice. Ed. Kaplan, B. et al., London: Kluwer Academic Publishers (2004).

4. R. F. Lusch, and S. Nambisan, Service innovation: a service-dominant logic perspective, MIS Quarterly 39(1) (2015) 155-175.

5. H. Zimmermann, Understanding the digital economy: challenges for new business models, AMCIS 2000 Proceedings (2000) https://papers.ssrn.com/sol3/ papers.cfm?abstract_id=2566095 [Accessed 20 July 2017].

6. A. M. Weber, What's So New About the New Economy?, Harvard Business Review January-February (1993)

7. C. L. Borgman, From Gutenberg to the global information infrastructure: Access to information in the networked world. (The MIT Press, MA, 2000)

8. S. Kotkamp, Pricing strategies for information products, Inhouse Manager, 3/00 (2000) 40-45.

9. R. Levacic, Markets and government: an overview, in ed. Markets, Hierarchies and Networks: The Coordination of Social Life, ed. G. Thompson (Sage Publications, London, 1998)

10. C. Anderson, Free: How today's smartest businesses profit by giving something for nothing (Hyperion, New York, 2009)

11. E. Coupey, Digital Business: Concepts and strategies (Routledge, New York, 2016).

12. H. A. Shelanski, Information, innovation, and competition policy for the internet (2013) http:// scholarship.law.upenn.edu/cgi/viewcontent.cgi? article $=1025 \&$ context $=$ penn law review (Accessed: 22 December, 2017)

13. S. Viswanathan and G. Anandalingam, Pricing strategies for information goods, Sadhana 30(2\&3), (2005) 257-274.

14. J. Kallinikos, A. Aaltonen and A. Marton, A theory of digital objects, First Monday: Peer-reviewed Journal on the Internet. 15(6) (2010). http://firstmonday.org/ ojs/index.php/fm/article/view/3033/2564 [Accessed 12 May 2017].

15. Y. Benkler, The wealth of networks: how social production transforms markets and freedom (Yale University Press, 2006).

16. S. Nambisan, K. Lyytinen, A. Majchrzak, and M. Song, Digital innovation management: reinventing innovation management research in a digital world, MIS Quarterly 41(1) (2017) 223-238.

17. A. Pfeiffer and M. Jarke, Digital transformation within the emobility market-learnings and insights from early market development, in SmartER Europe 2016/2017, eds. C. Derksen and C. Weber. IFIP AICT 495 (2017) 23-42. 
18. T. Rayna, Understanding the challenges of the digital economy: the nature of digital goods, Communications \& Strategies 71 3rd Quarter (2008) 13-36.

19. M. E. Porter, The Competitive Advantage: Creating and Sustaining Superior Performance (Free Press, New York, 1985).

20. H. Varian, Pricing information goods, Working Paper, University of Michigan, June (1995). http:// people.ischool.berkeley.edu/ hal/Papers/price-infogoods.pdf [Accessed 2 June 2017].

21. T. Kara and E. Baban, The effects of knowledge economy on the costs and cost comparison of traditional and digital goods, International Journal of Social Sciences and Humanity Studies, 3(2) (2011) online. http://www.sobiad.org/eJOURNALS/ journal_IJSS/arhieves/2011_2/tolga_kara.pdf [Accessed 13 June 2017].

22. G. C. Van Dusen, Digital Dilemma: Issues Of Access, Cost, And Quality In Media-Enhanced And Distance Education, ASHE-ERIC Higher Education Report 27(5) (2000). https://eric.ed.gov/?id=ED443371 [Accessed 13 May 2017].

23. P. F. Drucker, Managing in the next society (Truman Talley Books, New York, 2002).

24. S. Kukalis, A survey of recent developments in strategic management, International Journal of Management 26(1) (2009) 99-106.

25. K. Lorette, How e-commerce can reduce business transaction costs, Chron Small Business by Demand Media (2013). http://smallbusiness.chron.com/ ecommerce-can-reduce-business-transactioncosts-3503.html [Accessed 10 December 2017].

26. S. Greenstein, Transaction cost, transparency, and innovation for the Internet, FCC hearings, Innovation, investment and the Open Internet, January 13 (2009). https://docmh.com/download/documents/transactioncost-transparency-and-innovation-for-the-internet-byshane-greenstein-kellogg-school-of-managementnorthwestern-university-pdf [Accessed 13 December 2017].

27. J. Y. Bakos, Reducing buyer search costs: Implications for electronic marketplaces, Management Science, 43(12) (1997) 1676-1692.

28. J. P. Bailey, Intermediation and electronic markets: aggregation and pricing in Internet commerce, Ph.D. Thesis (Massachusetts Institute of Technology, Cambridge, MA, 1998a). http://citeseerx.ist.psu.edu/

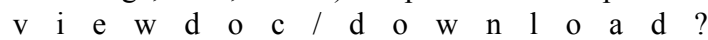
doi $=10.1 .1 .90 .1434 \&$ rep $=$ rep1\&type $=$ pdf [Accessed 18 June, 2017].

29. A. Ghose, and Y. Yao, Using transaction prices to reexamine price dispersion in electronic markets, Information Systems Research Articles in Advance (2010) 1-23.

30. S. Salop, Monopolistic competition with outside goods, Bell Journal of Economics 10(1) (1979) 141-156.
31. M. D. Smith, J. Bailey and E. Brynjolfsson, Understanding digital markets: review and assessment, MIT Working paper (1999). http://ebusiness.mit.edu/ $\begin{array}{llllllllllllllll}\mathrm{r} & \mathrm{e} & \mathrm{s} & \mathrm{e} & \mathrm{a} & \mathrm{r} & \mathrm{c} & \mathrm{h} & / & \mathrm{p} & \mathrm{a} & \mathrm{p} & \mathrm{e} & \mathrm{r} & \mathrm{s} & /\end{array}$ 140\%20erikb\%20digital\%20markets.pdf [Accessed 12 January 2017].

32. J. R. Brown and A. Goolsbee, Does the Internet make market more competitive?" Working paper. National Bureau of Economic Research (2000). http:// ideas.repec.org/p/nbr/nberwo/7996.html [Accessed 11 September 2017].

33. J. P. Bailey, Electronic commerce: prices and consumer issues for three products: books, compact discs, and software, Organization for Economic Cooperation and Development, OCDE/GD, 98(4) (1998b). http:// www.oecd.org/sti/35497325.pdf [Accessed 18 February 2017].

34. E. Brynjolfsson, Y. Hu, and M. D. Smith, Consumer surplus in the digital economy: Estimating the value of increased product variety at online booksellers, Management Science 49(11) (2003) 1580-1596.

35. K. Auletta, Publish or perish: Can the iPad topple the kindle and save the book business?, The New Yorker (2010). http://www.newyorker.com/reporting/ 2010/04/26/100426fa_fact_auletta?printable=true [Accessed 7 July 2017].

36. R. Jensen, The digital provide: Information (technology), market performance, and welfare in the South Indian fisheries sector, The Quarterly Journal of Economics 122(3) (2007) 879-924.

37. J. W. Pratt, D. A. Wise, David A. and R. Zeckhauser, Price differences in almost competitive markets, The Quarterly Journal of Economics 93(2): (1979) 189-211.

38. A. T. Sorensen, Equilibrium price dispersion in retail market for prescription drugs, Journal of Political Economy 108(4) (2000) 833-850.

39. D. J. Teece, Business models, business strategy and innovation, Long Range Planning 43(2-3) (2010) 172-194.

40. C. Zott, R. Amit and L. Massa, The Business Model: Recent Developments and Future Research, Journal of Management 37(4) (2010) 1019-1042.

41. A. Endersa and T. Jelassib, The converging business models of Internet and bricks-and-mortar retailers, European Management Journal 18(5) (2000) 542-550.

42. M. Rappa, Managing the Digital Enterprise: Business models on the web, Open Educational Resource, North Carolina State university (2010). http:// digitalenterprise.org/models/models.html [Accessed 11 June 2017].

43. C. Steinfield, H. Bouwman, and T. Adelaar, The Dynamics of Click-and-Mortar Electronic Commerce: Opportunities and Management Strategies, International Journal of Electronic Commerce 7(1) (2002) 93-119. 
44. P. Milgrom and J. Roberts, Limit pricing and entry under incomplete information, Econometrica 50(2) (1982) 443-460.

45. H. Lee, Do electronic marketplaces lower the price of goods, Communications of the ACM 41(1) (1998) 73-80. http://dl.acm.org/citation.cfm?id=268122 [Accessed 12 January 2017].

46. E. Brynjolfsson and M. Smith, Frictionless commerce? A comparison of Internet and conventional retailers, Working Paper (1999) http://ebusiness.mit.edu/erik/ frictionless.pdf [Accessed 8 March 2017].

47. A. Goolsbee, In a world without borders: the impact of taxes on Internet commerce, Working Paper, University of Chicago (1999). http:// faculty.chicagobooth.edu/austan.goolsbee/research/ intertax.pdf [Accessed 13 June 2017]

48. J. Alba, J. Lynch, B. Weitz, C. Janiszewski, R. Lutz, A. Sawyer and S. Wood, Interactive home shopping: consumer, retailer, and manufacturer incentives to participate in electronic marketplaces, Journal of Marketing, 61(3) (1997) 38-53.

49. A. Degeratu, A. Rangaswamy and J. Wu, Consumer choice behaviour in online and traditional supermarkets: the effects of brand name, price, and other search attributes, International Journal of Research in Marketing 17(1) (2001) 55-78.

50. D. Levy, M. Bergen, S. Dutta and R. Venable, The magnitude of menu costs: direct evidence from large U.S. supermarket chains, The Quarterly Journal of Economics 112(3) (1997) 791-825.

51. W. J. Adams and J. L. Yellen, Commodity bundling and the burden of monopoly, The Quarterly Journal of Economics 90(3) (1976) 475-498.

52. Y. Bakos and E. Brynjolfsson, Bundling information goods: pricing, profits, and efficiency, Management Science 45(12) (1999) 1613-1630.

53. D. L. McAdams, Multiproduct monopoly bundling, Working Paper, Graduate School of Business, Stanford University, Stanford, CA (1999). http:// citeseerx.ist.psu.edu/viewdoc/download? doi=10.1.1.43.2312\&rep $=$ rep1\&type $=$ pdf [Accessed 2 March 2017].

54. J. Chuang, Chung-I and M. A. Sirbu, Optimal bundling strategy for digital information goods: network delivery of articles and subscriptions, Information Economics and Policy 11(2) (1999) 147-176.

55. S. Wu, L. M. Hitt, P. Chen and G. Anandalingam, Customized bundle pricing for information goods: a non-linear mixed integer programming approach, Management Science, 54(3), (2007) 608-622.

56. A. Ghose, The economic impact of user-generated and firm-published content: directions for advancing the frontiers in electronic commerce research, in Statistical Methods in Ecommerce Research, eds. W. Jank and G. Shmueli. (Wiley Online Library, 2008). 